\title{
MORALE AMONG FRENCH COLONIAL TROOPS ON THE WESTERN FRONT DURING WORLD WAR I: 1914-1918
}

\author{
William Dean \\ U.S. Air Command and Staff College
}

\begin{abstract}
The traditional images of the French Army in World War I on the Western Front from Cyril Falls's to Marc Ferro's surveys (both entitled The Great War 19141918) have been that of the grizzled yet determined French peasant or worker - the poilu. It is clear from recent research that this is far from accurate and that the French forces were far more heterogeneous than portrayed by previous images. ${ }^{1}$ Men were called from all over the French empire to serve in the frontline and in logistics units. Virtually every part of the French Empire responded, although somewhat grudgingly, even including Tahiti, which provided a Bataillon Pacifique. Bringing men to a foreign land and culture to fight in a new type of horrific war was quite a strain on these 600000 soldiers. ${ }^{2}$ The bulk of these soldiers were drawn from North and West Africa, with smaller numbers coming from Madagascar, Indochina and Equatorial Africa. This article is an attempt at giving an impressionistic glimpse of this subject describing colonial morale both at the frontlines and behind the lines, seeing how they compare to their metropole comrades and trying to gain an understanding of the vie quotiedienne of the colonial soldier.
\end{abstract}

\section{Introduction}

France's empire in Africa and South East Asia had been carved out with indigenous and European colonial troops and this army was divided into two branches: the Armée d'Afrique, which included Zouaves, the Foreign Legion, Bataillon Afrique and Algerian and Tunisian tirailleurs; and the Armée Coloniale, which included such units as Senegalese and Vietnamese tirailleurs as well as some white units (originally marines). Not all units in the Armée d'Afrique were made up of local levies; the Zouaves were an all-white unit with continental Frenchmen and men coming from pied noirs. ${ }^{3}$ Colonial officers like General Charles Mangin had called for the creation of a force noire to offset France's demographic decline vis à vis Germany. There were 30000 Tirailleurs Sénégalais and 35000 Algerians, most 
of whom had extensive combat experience under arms in $1914 .{ }^{4}$ Added to this could be included the Zouaves and the then infamous Foreign Legion. Most archival material on morale was generated from the fall of 1917 in the wake of the army mutinies, but some camp reports before 1917 can give some glimpse of morale and daily life.

When the war broke out, the French were still in the process of conquering Morocco, where many of its premier troops were. A Moroccan division was created, which was a mélange of French troops, Zouaves (mostly European North Africans), tirailleurs and some West African troops. ${ }^{5}$ Algeria (which was the headquarters for the XIX Army Corps) and Tunisia immediately supplied 13 battalions of Zouaves and 16 battalions of tirailleurs. These formed the $37^{\text {th }}$ and $38^{\text {th }}$ divisions. Approximately 104 battalions were sent from North Africa during mobilisation. North African units faced heavy combat from the marshes of St Gond during the battle of the Marne and the subsequent race to the sea.

There were also some West Africans who were grouped under the title "Senegalese" who went to and from these units, and who only fought in battalionsize units, hence the name Bataillon Tirailleurs Sénégalais, or simply BTS. Seven BTS units coming from North Africa (mostly combat veterans from Morocco) arrived in France at the end of September 1914. These troops were sent to the front with practically no period of adaptation or preparation ${ }^{6}-$ "[t]he African troops were always placed in the most dangerous posts". 7 In these tirailleurs units the officers, non-commissioned officers (NCOs) and the machine gunners were white. In general, the BTS units did well, apart from the one case of the $1^{\text {st }} B T S$ panicking in combat in Arras. This one case was used by the high command to discredit the use of black African troops on the Western Front. Whether there was panic or not, by November the BTS had lost $67 \%$ of their black infantry men and $18 \%$ of their white cadre. ${ }^{8}$ Added to this, the black Africans who were used to a much warmer climate were suffering from the cold damp climate of northern France. The army sent these men to southern France or to North Africa in what became known as hivernage. This concept of hivernage was practiced with most troops from subtropical climates, as can be illustrated by the order for hivernage of the Creole troops of the West Indies. ${ }^{9}$ In 1915 the "Senegalese" saw no action on the Western Front, but were sent to participate in the Dardanelles fiasco.

1914 was not a good year for indigenous (Arabs and Kabyles) or European Algerians and Tunisians. Most of the men were volunteers and some were combat veterans of colonial wars. The mobilisation for the war occurred in the midst of Ramadan, which must have caused some anxiety. The losses of the tirailleurs, 
compared to the relative small numbers deployed were heavy in the opening months of the war. Of the 35000 Algero-Tunisians deaths for all of World War I, 6500 were killed in the first five months of the war. "The probability for an Algerian to be killed at the front was nearly six times greater in 1914 than in 1918." "While the best battalions fought well, others less well-trained panicked and broke."11 There were small-scale mutinies and the case of Lieutenant Boukabaya leading his Algerians to the German lines. ${ }^{12}$ Fleeing from the battlefield was treated quite horribly. On September 7 near l'Ourcq, 12 Zouaves were shot for fleeing as an example to the other men. In another sector, 12 men who fled the battlefield (Fayards) from the $5^{\text {th }}$ Tirailleurs Algerien were shot as examples to the other tirailleurs. ${ }^{13}$ In the middle of December 1914, General d'Urbal ordered that the 8th Tirailleurs Tunisien with any company that refused to march or obey orders should seen every $10^{\text {th }}$ man be chosen to first wear a sign written in French and Arab that said "Coward" and then be shot". 14

Obviously, morale was poor in these North African units and the French became very concerned about North African loyalty. Of course, the French were worried about morale not only because of minor mutinies but also because the Ottoman Empire had entered the war and the Germans were using this to propagandise the Algerian and Tunisian people. Some of the first colonial morale reports appeared in January 1915. On 11 January 1915, the Minister of War, Alexander Millerand, wrote the following to the Commander-in-Chief Joseph Joffre:

I have the honor of informing you that the necessity of safeguarding the loyalty of our muslim [sic] troops has preoccupied me since the day that Turkey entered the European conflict. To this effect, I have called from Algeria, Tunisia and Morocco numerous officer/interpreters that I have attached to the training depots and sanitary installations with the mission to survey the state of spirit of the military natives and to combat the antiFrench schemes of which they could be the object. ${ }^{15}$

The French concern over morale was political. It should be noted here that morale among French troops was fairly good until the crisis of late spring and summer 1917. Morale among French metropolitan troops recovered in late fall 1917 and continued to improve throughout $1918 .^{16}$

In this same report, the French racist perception of warrior peoples versus effete peoples can be seen. Millerand writes: "The state of spirit of the native Tunisians leaves something to be desired. That is their nature though to be less warlike than their co-religionists, the Algerians and Moroccans". ${ }^{17}$ This absurd view of 
warrior races was applied to the Vietnamese (with the Tonkinese being the warrior race) and the West Africans. This was a widespread belief among colonial armies with, for example, the British believing that Indians from Punjab were more warlike than those from Bengal. The pseudo-anthropological concept of warrior and effete races or masculine and feminine races was the European intellectual attempt at understanding the various peoples of Africa and Asia. It was a highly arbitrary construction that was superficial but nonetheless impacted how the French colonial army trained and equipped their indigenous soldiers. French attitudes to various groups had an effect on how they were organised and how they were used in battle and behind the lines - all of which affected morale.

Not only were there morale and combat-performance problems with North African and West African units. There were also profound problems of organisation and morale in the most famous French colonial unit, the Foreign Legion, which was known for its élan. Since French law forbade foreigners from serving in regular French line units, all foreign volunteers in 1914 were placed in the Legion. This included eastern Europeans, Jews who had fled to France in the wake of fin de siécle persecution, Russian leftists and almost a thousand Greeks, Italians, Swiss and enthusiastic American youths. ${ }^{18}$ "But the outlook, mentality and social backgrounds of the Africans [the old veterans] were so radically different from that of the new men that the amalgamation promised to be a stormy one." 19 Middle-class intellectuals had a very difficult time taking orders from grizzled anti-intellectual sergeants and fistfights were not unknown. Even when the Legion became desperate for men, the naïve Englishman Maurice Magnus recorded his first reception as a cold one:

A tall good-looking officer, obviously a gentlemen came up to me and asked me in English what I was doing here. Was it really so extraordinary that a fairly decent person should enlist in the Legion? It was - only I did not know it then. ${ }^{20}$

The Foreign Legion was hampered by poor leadership, which added to poor morale. ${ }^{21}$ The amalgam created so many problems, including mutiny, that in 1915 most of the foreigners were allowed to leave the Legion, and soon there was a scramble to leave it. ${ }^{22}$ The strength of the Foreign Legion dropped from 21887 in 1915 to 10683 in 1916, of which 3316 served on the Western Front. ${ }^{23}$ Most legionnaires were serving in Morocco in 1916 or in other colonies trying to maintain a minimum of control. 
Despite popular mythology, which holds the Foreign Legion to be the home of the social refuse of the West, there was one unit that was filled with many more blackguards and anti-social deviants, namely the Bataillon d'Afrique (known at the Bat d'Af or Les Joyeux). ${ }^{24}$ Just as the other colonial units, in the first two years of the war, the Bat d'Af suffered from poor morale and even worse combat performance. There is little written about this small but infamous unit, but the entries in the Bat d'Af's Journal de Marche gives some idea about problems within this unit. After being gassed in late 1915, the unit had to be reconstructed. Colonel Mordaq listed the following complaint/plea in the Journal de Marche in January 1916:

The last re-enforcements that arrived were composed in large part of the worst of North Africa. About a third of the re-enforcements deserted en route to the front. Those that came brought indiscipline to the battalion (e.g. mutiny at Brincourt). ${ }^{25}$

Mordaq continued that he did not want the refuse of the army, especially those who have been court-marshalled, and that this unit should spend some time in the rear (which it did) for retraining. ${ }^{26}$

It is clear that all of the illustrious colonial units that had fought so well in the last 20 years of the $19^{\text {th }}$ century had poor morale and uneven combat records. Poor morale came from poor training, inadequate leadership among officers and NCOs, unequal pay and leave and poor living conditions. One unit, however, did quite well in the beginning of the war, namely the Regiment Infanterie Coloniale $d u$ Maroc. Formed in 1915, this unit was a mélange of various tirailleurs units (with no Moroccans), and was one of the most decorated units of the war. ${ }^{27}$ This unit was an exception to the general trend.

As France needed more and more men in 1916, they brought in units to the Western Front from Indochina and Madagascar. The Western Africans were also recalled. This came about because of the two failed offensives in 1915 and the slaughterhouse of Verdun. Greater care was taken in the future training and housing of these units. A document (no author listed) entitled "Note on the subject of the Berber Army" reported as follows:

The effectives, which France has at her disposal, have been tested by fifteen months of war ... The numbers of effectives are, in effect, a guarantee of the duration of the war if this duration is necessary; it is a condition of success if the struggle calls for sacrifices of a considerable 
amount of men. Different means have to be envisaged to maintain our effectives at the necessary level: drafting younger classes, forming a black army, forming a native army recruited from all of our possessions except North Africa. ${ }^{28}$

North African soldiers' morale improved steadily after 1915 because of improved training, but there were still many problems. The French did not quite trust the tirailleurs in combat and so they mixed tirailleurs with Frenchmen and European Zouaves in the following manner:

\section{OXXXOXXXOXXXOXXXOXXXOXXXOXXXO \\ OXXXOXXXOXXXOXXXOXXXOXXXOXXXO \\ OXXXOXXXOXXXOXXXOXXXOXXXOXXXO \\ $\mathrm{O}=$ French soldier $\mathrm{X}=$ Algerian Tirailleur ${ }^{29}$}

There were now mixed regiments of tirailleurs and Zouaves because of the large number of desertions in $1915 .{ }^{30}$ Zouaves tended to perform better as shock troops and they were also proficient in all aspects of trench warfare. It took longer for the indigenous Algerians and Tunisians to adapt to warfare, but by 1917 they came to relish using machine guns and fighting in tank assaults. ${ }^{31}$ The improved combat performance related to improved training, housing and morale.

Starting in February 1916, the French government began to work hard on improving morale. For example, Officer-Interpreter First Class Saint-Blanant wrote to the commander of the $17^{\text {th }}$ Military Region:

By ministerial decision, smoking tobacco and snuff will be distributed free of charge to native soldiers who are being treated in hospitals beginning February. This gracious measure has produced a very good effect on our tirailleurs. ${ }^{32}$

In general, the interpreter reported that morale was good, but many who had been in France for 14 months asked to be sent home to convalesce. ${ }^{33}$ It was not until 5 September 1917 that there was complete equality between French and Algerians in terms of leave. ${ }^{34}$ In 1916, the biggest issue the French were concerned with in terms of hospital care was the intimate relations between native North Africans and the female nurses, who Meynier calls Vierges Laique. In June 1916, no female personnel were allowed to work in hospitals. ${ }^{35}$ Perhaps this was done out of concern for the morale of white French troops at the front, rather than an act of sexual 
prudery. As further proof of this, the French did not regard homosexuality among Algero-Tunisan troops as taboo. ${ }^{36}$ To make the North African Muslims more at home in the hospitals, couscous was served and imams served as chaplains. ${ }^{37}$

Housing for the North Africans was not always good, but French military authorities did have inspectors in 1916 who tried to ensure that the tirailleurs lived in acceptable conditions. In an inspection report dated 1 October 1916 concerning the depot of the 5th Tirailleurs Algerien (Aix en Provence), it was reported that the men placed in the Forbin barracks had sufficient bedding and heat. ${ }^{38}$ The latrines were sanitary and the hot showers worked. ${ }^{39}$ The second barracks was in good shape, but the third and last barrack, and old convent, was nearly uninhabitable, with dangerous heating and defective latrines. ${ }^{40}$ It seemed apparent from the report that the few tirailleurs who were in the convent were to be moved.

Throughout much of the war, the Tunisians seemed to have the worst morale. This can be seen clearly in the Tunis military postal control. The Tunisian tirailleurs Tidjoni Ben Sadak wrote in October 1916:

We are exposed to bombs sent against us. The Christian cheapens our existence. I beseech thee, my God, to save us, to cease our separation from our family and to recall us home from this unhappy army. ${ }^{41}$

In April 1917, a report on Tunisian postal control said that most complaints were of poor food and supplies. The most common demands were for chocolate, dates and dried cake. ${ }^{42}$ Other soldiers complained of poor sleeping conditions and cowardly officers. Tirailleur Benda Leon wrote: "We sleep in barns on a little straw. The officers that we hardly see at the front line shit on us now and at all times". ${ }^{43}$ According to the unnamed officer who wrote this report, the Tunisian tirailleurs said that they suffered from general lassitude but that this did not compromise their hope for final success. ${ }^{44}$ During the mutinies of the summer of 1917 , none of the Tunisians revolted. In fact, none of the North African units revolted, and North Africans were used to keep order in suspect units and guard the train stations. ${ }^{45} \mathrm{~A}$ letter written on 14 November 1917 after the battle of Malmaison documented some examples of good morale in the Tunisian postal control. Salah el Abide of the $8^{\text {th }}$ Tirailleurs wrote of an attack:

Towards five o'clock in the morning, the infantry showed an irresistible élan. Each regiment, each battalion knew the objective. If it happened that it [the regiment] was soon stopped other waves of the assault would continue to advance. ${ }^{46}$ 
In morale reports that were issued throughout the army in the wake of the mutinies, Tunisian morale seemed to be troublesome, but with signs of improvement. Most soldiers analysed in the reports believed France would be victorious and that the military hardware was good. In contrast, most soldiers who responded to these reports were critical of military supplies, the high command and leave policy. ${ }^{47}$ On 9 December 1917, the Minister of War told all commanding generals that Algerian and Tunisian tirailleurs were to get 30 days leave if they had been away from their families for six months or more. ${ }^{48}$

The morale of some of the Algerians and Tunisians who fought with the Zouaves in mixed units seemed to be fairly good - it seemed that they were resigned to beating the Germans in the bloody Nivelle offensives in the spring of 1917 . Nahoum of the $3^{\text {rd }}$ Zouaves (a mixed unit) wrote in May 1917:

The Zouaves, despite their heroism, could not advance. We have had many losses. My commander, a charming man, was wounded at the beginning of the attack, but, without our sacrifice, the advancing troops of the left and right flanks could not have inflicted heavy casualties on the enemy. ${ }^{49}$

This quote illustrates the importance of leadership for good combat soldiers with high morale.

Officers being able to speak Arabic also contributed to good morale. Men like Captain Baril, who lived like an ordinary tirailleur, or Colonel Schultz (an Alsatian), both learned Arabic in the trenches and were loved by their men. ${ }^{50}$ There were cases where French troops and Arabs were involved in fistfights, especially during the summer of 1917 , but towards the last year of the war there were growing feelings of solidarity between French tirailleurs serving with the North Africans. This was expressed in the saying "We all are in the same shit". ${ }^{51}$

Very good morale was reported in the morale report of the $1^{\text {st }}$ regiment of Algerian tirailleurs of 29 September $1917 .{ }^{52}$ The soldiers asked for couscous and mutton and complained that some of their uniforms were defective. ${ }^{53}$ The Algerians were reported as not being pessimistic, but fatalistic, and there was a rest at Ramadan with native customs respected. ${ }^{54}$ It was reported that desertions were very rare. ${ }^{55}$ In a report dated 4 November 1917, it was stated that the second mixed regiment of tirailleurs and Zouaves were in good spirits, ${ }^{56}$ and that food and clothing were good and that the authorities were seeing to it that merchants were not selling wine to the soldiers. ${ }^{57}$ This report also noted that the Algerians loved the 
cinema. ${ }^{58}$ There seems to have been a "bread and circuses" approach to improving colonial troop morale in the fall of 1917. In general, morale reports of late 1917 said that all French soldiers were heartened by the fact that the Americans were entering the war, but were discouraged by the collapse of the Eastern Front.

In the beginning of 1918, troop morale among Algero-Tunisian tirailleurs continued to be very good. This is shown by two reports in January and February. ${ }^{59}$ In the $4^{\text {th }}$ Zouaves, morale was generally quite good, but this partially depended on whether the soldiers were old hands or replacements. ${ }^{60}$ Most of the replacements had been serving in southern Tunisia and had not seen combat. Their morale was mediocre. ${ }^{61}$ It was believed that morale was strong enough among the veterans to keep the "bad influences" in check. ${ }^{62}$ Throughout World War I, the Zouaves received the best care and had the highest morale of all the units of the Armée d'Afrique.

The Zouaves and the Algero-Tunisian tirailleurs were in very heavy fighting and they did well. The ranks of the tirailleurs swelled in 1918 by 46000 men - the highest draft of the war, which was called by Georges Clemenceau or any other premier. ${ }^{63}$ The Tunisians, however, did not do as well as the Algerians, as illustrated by a rise in desertion. ${ }^{64}$ The total casualties in battle for indigenous North Africans were 36000 Algerians and 10000 Tunisians.

As West Africans began to report to the Western Front again in 1916 for the Battle of the Somme, ad hoc housing arrangements were made for them. Many of the barracks created for the West Africans were unsatisfactory. From April 1916 their numbers went from 10000 to 40000 in the late fall. ${ }^{65}$ At one of the major camps, Corneau, conditions were deplorable. By that fall, and African member of the Chamber of Deputies, Blaise Diagne called for the camp to be closed. The Camp Commandant, Colonel Fonnsagrives, wrote a report on 1 November 1916 to the Director of Colonial Troops, General Famin, in which he said:

The camp is obviously not perfect, there is still much to be done, but there is already much done and the sanitary state gets better each day and so the lower mortality rate proves that the improvement is already sensible. Good will helps all the camp, which will in a little time be among the best. $^{66}$

Clearly, Diagne's entreaties had an effect. 
The Camp Commandant said he had not yet distributed winter clothes because the weather had been mild. The West Africans' living conditions improved because they had gone from living in tents to prefabricated Adrian barracks. The barracks tended to get too hot during the day and too cool at night. ${ }^{67}$ Heating was a problem because of an administrative backlog on fuel. There was still no electricity and the soldiers used oil lamps which were not safe. ${ }^{68}$

Food for the West Africans was abundant. However rice was served frequently as staple. Doctors worried about beriberi, which they believed came from eating too much rice. ${ }^{69}$ To entertain the troops, a cinema and Sudanese musical instruments were provided. There was also a theatre and soccer to relieve boredom. ${ }^{70}$ Colonel Fonnsagrives closed his report by saying that the camp could no longer be referred to as Camp de la Misére. ${ }^{71}$ Blaise Diagne continued his complaints, but they fell on deaf ears.

Religion was particularly important in West African camps and in general, imams preached fidelity to the French to the West Africans. It was easier for the Muslims than the animists to practice their religion in France, because animist rituals were difficult to transport. The French Army refused to allow the Catholic Church to work with the BTS for fear of proselytising, which disrupted morale. Not even the White Fathers with extensive experience in Africa were allowed to work with the tirailleurs. $^{72}$

In the 1917 Nivelle offensive there were 34 BTS units available and 24 were placed in combat. ${ }^{73}$ The West Africans were sent to General Mangin, the man who before the war had promoted the idea of the force noire. Between 20 March and 1 April they were brought up to the front. The winter of 1916/1917 had been one of the coldest on record, and when the West Africans arrived at the front it was still cold with abundant snow and sleet. The result was that many of the men of the BTS became sick with pulmonary problems.

The BTS that were sent into combat did not have any grenades, signal guns or machineguns: "In a word the tirailleurs only had a few cartridges, bayonettes [sic] and their coupe-coupe" ${ }^{74}$ The infamous coupe-coupe was a long knife, with which the West Africans had the mythic reputation of beheading the Germans, since they took no prisoners. Mangin absurdly believed that the "Senegalese" were shock troops par excellence because their apparent phlegmatic demeanour meant that artillery shelling did not upset them as much as it did the white soldiers. ${ }^{75}$ Most Senegalese performed extremely well despite the high casualties, which eventually earned Mangin the name "Butcher". The BTS lost $62.5 \%$ of their men engaged in the 
Nivelle offensive. ${ }^{76}$ There were understandably a few cases where the Senegalese fled the battlefield. Despite overall bravery, Senegalese battalions were amalgamated into larger white units - usually colonial infantry units.

During the French Army mutinies that summer, the BTS's morale was good, despite heavy losses, and only one unit, the $61^{\text {st }} B T S$, mutinied in the evening of 13 August 1917. When their battalion was asked to go to the front, the men said they were tired as they had only been out of the trenches for a couple of days, and asked whether they could rest some more. ${ }^{77}$ No amount of prodding could get them to go, so General Puyperoux decided to meet with the $61^{\text {st }} B T S$, hopefully unarmed, at 07:15 the next morning. The next morning, those troops who were rebelling (a minority) refused to lay down their arms. According to the report of Puyperoux, they said, "Battalion Malafosse [ $\left.61^{\text {st }} B T S\right]$ is no good; never any rest, always making war, always killing blacks ..." ${ }^{78}$ General Puyperoux was faced with two alternatives: find a battalion of European troops with machine guns and 75s and shoot it out with the mutineers, or send them to the rear and weed out the ringleaders. ${ }^{79}$ Puyperoux was instructed by General Maziller, Commander for the First Colonial Army Corps, to send them to the rear. ${ }^{80}$

In 1918 , the $61^{\text {st }}$ BTS was reconstituted and performed quite well. ${ }^{81}$ General Puyperoux had recommended against a massacre of the West Africans because he felt it would have "a disasterous [sic] effect on all Senegalese units as well as Madagascar and Tonkinese who would not hesitate saying the whites massacred them". ${ }^{82}$ The revolt was the only example of a serious discipline problem among West Africans, and this mutiny was spontaneous and motivated by the same | reasons as in the white units. General Maziller said that BTS should be mixed in with French troops in the future to prevent rebellion. ${ }^{83}$

In 1918 , the BTS were in good spirits. This is summed up by the statement "Avant j'etais nègre, maintenant je suis français" [before I was a Negro, now I am a Frenchman]. ${ }^{84}$ All the morale reports showed that the West Africans were in good spirits. They performed well in the July offensives in 1918, making up a sixth of the $1^{\text {st }}$ Colonial Army Corps. Part of this performance was due to the fact that they were given up-to-date weapons like grenades and trench mortars. In October, the $69^{\text {th }} B T S$ took over 1800 German prisoners. ${ }^{85}$ In a morale report dated 5 November 1918 , Chef de Bataillon Laforegere says of the $75^{\text {th }}$ BTS:

The Senegalese are confident that their commanders will lead them to victory but given the late date the weather is affecting morale. Besides 
the weather the only other complaint the West Africans have is a lack of Kola Nuts. ${ }^{86}$

Many of the Senegalese were homesick. ${ }^{87}$ The West Africans were homesick because they were not allowed to return to West Africa for the duration of the war. This was justified because of logistical problems and a lack of vessels for transportation. ${ }^{88}$ This was the principle source of the blues among West African troops, but nonetheless did not wreck morale. ${ }^{89}$

The cost of the war was high for the West Africans: Approximately 134000 men participated in combat and 29520 were killed. ${ }^{90}$ The drafting of so many men followed by the great number of deaths caused severe social and economic distress and dislocation in West Africa. ${ }^{91}$ The French government of course did not care about this and had the war dragged on, they would have used Senegalese in 1919. As it was, West Africans were used in the French Army in combat until 1954.

In 1916, the Foreign Legion was smaller and saw little action on the Western Front, but the Legion did participate in the Nivelle offensives and took heavy casualties. ${ }^{92}$ The Legion did not experience any mutinies in the summer of 1917 and they were used to being the ones to seal off the roads and return the mutineers to the front. ${ }^{93}$ In the beginning of 1918 , according to a morale report by Chef de Bataillon Colin on 23 February, the Legion's morale was excellent, but Colin strongly urged a respite behind the lines. ${ }^{94}$ Food was sufficient but of little variety, but most important to the Legionnaires, wine was easily obtained. ${ }^{95}$ The Legionnaires were not concerned about the collapse of the Eastern Front and the leave situation was quite good. ${ }^{96}$ The report said that the civil populace even seemed to like the Legionnaires. ${ }^{97}$ The Legion had one main problem, which was a shortage of new recruits. They tried to compensate for this by taking imprisoned mutinous Russians from prison camps in Morocco, but they simply deserted to the Germans. ${ }^{98}$ The only reliable foreigners they received were Swiss and Spaniards. The Legion did very well in the allied counter-offensive in July 1918 and they helped spearhead Foch's offensive using new infiltration tactics. In terms of casualties, the Legion lost 4116 men on the Western Front, while most of its deaths occurred on other fronts. ${ }^{99}$ The Legion of 1918 had better morale and combat performance than that of $1914 / 1915$.

The sending of Indochinese troops to France in 1916 was an act of desperation. A total of 43430 troops were sent to France during World War I and of 
these, there were four battalions of combat troops and 15 battalions of logistics troops. ${ }^{100}$ Many of the Vietnamese, like the West Africans, needed to be wintered in the south of France. In a morale report of the $3^{\text {er }}$ Bataillon Indochinois, written on 10 September 1918, Captain Colin said that the Vietnamese were having a difficult time adjusting to the climate. ${ }^{101}$ The Vietnamese do not like bread and insisted on rice for their rations. ${ }^{102}$ Despite these issues, it was reported that the Vietnamese spirit was enthusiastic. $^{103}$

Reports for two years earlier showed a shakier situation. In the Journale de Marche for the $13^{\text {er }}$ Bataillon Tirailleurs Indochinois the shipping of this unit in 1916 was discussed. Some of the men of this unit became infected with cholera, of which 99 died (in a unit of 1200 men). The latrines were unsanitary and the cuisine was unsatisfactory. ${ }^{104}$ Again we see the pattern, as in other colonial units, of general improvement by 1918. In a Journale de Marche for May 1917 on the $16^{\text {th }}$ Supply Battalion it was stated that the tirailleurs had high morale and gave the maximum effort. $^{105}$

A morale report of September 1917 said the Vietnamese functioned well in the trenches as long as they were given regular respites behind the lines. The $3^{\text {rd }}$ Battalion was in good spirits with no problems of demoralisation. Perhaps the most demoralising event for the Vietnamese was receiving letters from their wives with the news that they had remarried. In this same compte-rendu, the French officers saw how the Vietnamese of the $11^{\text {th }}$ Tirailleurs celebrated Têt to get a better picture of morale. There were problems with retraining troops in the winter of 1917, as illustrated by a report written by chef d'État Major Pelain to GQG (Headquarters) on 2 November 1917. In this report, he said the Cochin Chinese were more sensitive to the cold than other groups and should be sent to the south of France first. ${ }^{106}$ It seems that there were some sanitary problems in the winter quarters and there is mention of a possibility of an epidemic of dysentery. ${ }^{107}$ In general, the Vietnamese were given hazardous construction jobs near the front. Most Vietnamese who fought at the front did well, and there were no mutiny problems with the Vietnamese in 1917. In Indochina, the massive recruiting campaign caused a few local insurrections and men mutilated themselves or jumped off ships in order to avoid going to France. ${ }^{108}$ Once the Vietnamese made it to France, they accepted their lot and performed any task assigned to them well. At the end of the war,

... the Vietnamese troops who returned from France with a new outlook on life were particularly disappointed. They realized that neither they nor their country would be rewarded for the services that had rendered France. $^{109}$ 
The same could be said of the West Africans, Algerians and Tunisians.

In general, French colonial troops from Foreign Legionnaires to West African tirailleurs seem to have suffered from low morale from 1914 to 1916 . This was contrary to the fairly high discipline of the French metropolitan citizens (both combatants and non-combatants), as has been illustrated by Jean-Jacques Becker in The Great War and the French people. The low morale of the colonial troops was due to the infamous system " $D$ " (a nickname for supply and organisation), which was characterised by poor supply and organisation. ${ }^{110}$ This ad hoc system brought about poor housing, with the West Africans living in tents in 1915, as well as loss of life, colonial soldiers being thrown into battle without being retrained, failure to recognise the harsh effects of the northern French climate on people used to the tropics and poor nutrition.

Racism influenced everything, from the prohibition of female nurses in hospitals to battle organisation. Certainly, both the Arabs and West Africans in particular were made to feel inferior by their officers and NCOs, especially with the great inequity with regard to leave. Heterogeneity complicated the war effort, given the special dietary and climate needs of many of the colonial troops. Heterogeneity also created problems of command and control, for there was always a shortage of officers who spoke Arabic for the North Africans, much less Bambara, Tukolor, Vietnamese and a host of other languages. This lack of communication was a source of low morale. By 1917, especially in the wake of the Army Mutinies, the French government and army made a serious effort to improve the colonial soldiers' living conditions, and this paid off with higher morale and good combat performance in 1918.

The effort of 600000 soldiers contributed to France staying in World War I and the country's ultimate victory. Thousands of Germans were released from the Eastern Front in 1918 and the colonial troops holding the line helped to save France in a precarious conflict. The price that the colonial empire paid was high, with economic and demographic dislocation, and the veterans who returned to their homelands in 1919 played a part in the growing nationalism of the inter-war years, which set the stage for post-1945 revolutions in the French Empire.

In the inter-war years, the French government came to rely more and more on colonial troops. Thousands of French colonial troops were sent to the Rhineland to occupy this German region. The local Rhinelanders thought that French colonial soldiers, especially the West Africans, were brutal savages and rapists. ${ }^{111}$ They referred to the French use of colonial troops of color for occupation of the Rhineland 
as the "Black Shame" and later Hitler used this experience to advance his political career. Numerous French colonial troops fought in the proto-nationalist Rif Rebellion in Morocco in 1925 to 1926 and the Druze Rebellion in Syria in 1925 to 1927. With the growing demographic crisis of the hollow years of the 1930s, the French Army increased its reliance on colonial troops. ${ }^{112}$ By 1940, a much higher percentage of the French Army came from the colonies than during the Great War. Most of the indigenous troops that fought the Wehrmacht were from North or West Africa. The first inkling of nationalist problems in the ranks of the French colonial army came at Yen Bay in Tonkin in 1931. Here, a Tirailleur Tonkinois regiment rose up against its European officers and NCOs. This was a foreshadowing of the nationalist and Marxists colonial rebellions that the French would fight after World War II, but this is the topic of another work.

Endnotes

1 The author attempted to synthesise the works of Marc Michel on the Senegalese and Gilbert Meynier on the Algerian indigenous experience in World War I, plus to add some of his own research on various colonial units in World War I. See Michel, M. 1982. L'Appel a L'Afrique: Contributions et Reactions a L'Effort de Guerre en A.O.F. [Afrique Occidental Francaise] 1914-1919. Paris: Presse Universitaires de France and Meynier, G. 1981. L'Algerie Revelee: La Guerre de 1914-1918 et Premier Quart du XX eme Siecle. Geneva: Librairie Droz.

2 For numbers, see Porch, D. 1988. French Army in the First World War. In Millet, A \& Murray, W (eds.). Military effectiveness Vol I: The First World War. Winchester, MA: Unwin: 197.

3 Pied noirs ("black feet" or "black shoes") were somewhat pejorative terms used to describe French settlers in Algeria. Ibid., p. 198.

Meynier op. cit., p. 259.

Michel op. cit., p. 288.

Ibid., p. 288.

Ibid., p. 291.

Service Historique, Armée de la Terre (S.H.A.T.) 7N1992; Series N concerns World War I.

Meynier op. cit., p. 274.

1 Clayton, A. 1988. France, soldiers and Africa. London: Brasseys: 248.

Ibid., p. 249.

Meynier op. cit., p. 275.

Ibid., p. 276.

5 S.H.A.T. 16 N194. 
16 See Becker, J.-J. 1985. The Great War and the French people. Dover, New Hampshire: Berg: 94-96, 111, 116, 194, 217-248, 302-316 for detailed graphs and information on the morale of French metropolitan troops on leave and the morale of French civilians on the home front.

17 S.H.A.T. $16 \mathrm{~N} 194$.

18 Porch, D. 1991. The French Foreign Legion: A complete history of the legendary fighting force. New York: Harper Collins: 334-339.

19 Ibid., p. 340.

20 Magnus, M. 1925. Memoirs of the Foreign Legion. New York: Martin Secker: 117.

Porch op. cit., 344.

Ibid., pp. 358-363.

Ibid., p. 363.

They were given the title Les Joyeaux because of their constant grumbling. Many of the men were pimps in civilian life.

S.H.A.T. 26N859.

S.H.A.T. $26 \mathrm{~N} 859$.

On organisational breakdown, see Clayton op. cit., p. 95.

S.H.A.T. 7N2109.

From Meynier op. cit., p. 419.

Ibid., p. 418.

For details, see Ibid., pp. 428-431.

S.H.A.T. 7N2113.

S.H.A.T. 7N2113.

Meynier op. cit., p. 425.

Ibid., p. 439.

For further comment on Maghribian homosexuality, see Ibid., p. 439.

Ibid., p. 438.

S.H.A.T. 7N2113.

S.H.A.T. 7N2113.

S.H.A.T. 7N2113.

S.H.A.T. 7N1001.

S.H.A.T. $7 \mathrm{~N} 2107$.

S.H.A.T. 7N2107.

S.H.A.T. 7N2107.

Meyneir op. cit., pp. 435-436.

S.H.A.T. 7N1001.

S.H.A.T. 7N1001.

S.H.A.T. $7 \mathrm{~N} 2113$.

S.H.A.T. 7N1001.

Meynier op. cit., p. 400.

Ibid., p. 442.

S.H.A.T. 7N1517.

S.H.A.T. $16 \mathrm{~N} 1517$.

S.H.A.T. $16 \mathrm{~N} 1517$. 


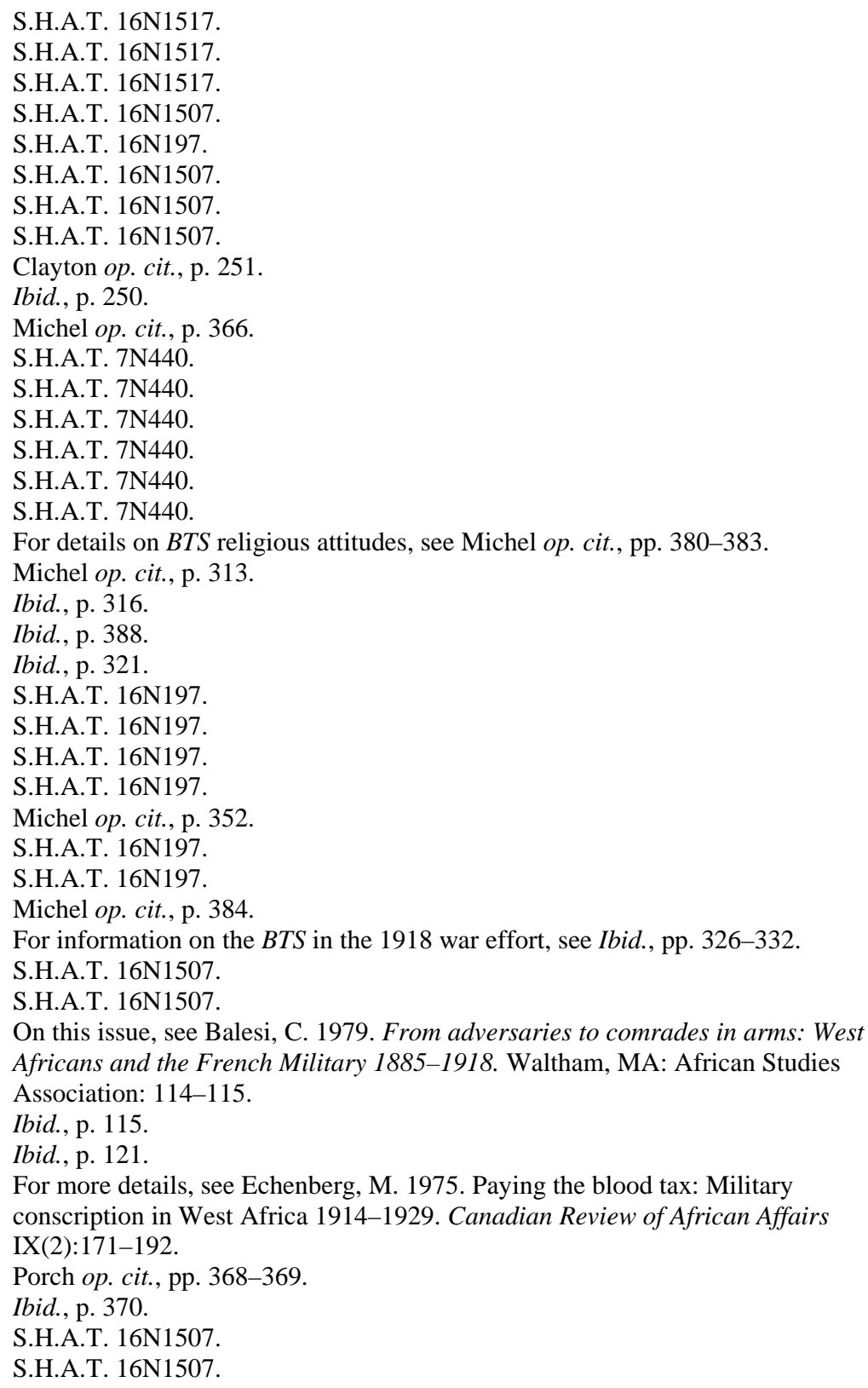


96 S.H.A.T. $16 \mathrm{~N} 1507$.

97 S.H.A.T. $16 \mathrm{~N} 1507$.

98 S.H.A.T. 16N1507, “Comte Rendu Capitain Rollet”, 10 August 1918.

99 Porch op. cit., p. 380.

100 S.H.A.T. 10H18, "Historique de Tirailleur Tonkinois 1914-1918".

101 S.H.A.T. $16 \mathrm{~N} 1507$.

102 S.H.A.T. $16 \mathrm{~N} 1507$.

103 S.H.A.T. $16 \mathrm{~N} 1507$.

104 S.H.A.T. $26 \mathrm{~N} 874$.

105 S.H.A.T. 26N874.

106 S.H.A.T. 25N551.

107 S.H.A.T. $25 \mathrm{~N} 551$.

108 For details, see Buttinger, J. 1967. Vietnam: A dragon embattled, Vol. I. New York: Praeger: 96-100.

109 Ibid., p. 101.

110 Although mobilisation went far better in 1914 to 1916 than in the FrancoPrussian War.

${ }^{111}$ On this view, see Nelson, K. 1970. The Black Horror on the Rhine: Race as a factor in post World War I diplomacy. Journal of Modern History 42:605-662.

112 See Weber, E. 1994. The hollow years: France in the 1930s. New York: Norton: 251. 